\title{
PISA, policy making and political pantomime: education policy referencing between England and Hong Kong
}

\author{
Bob Adamson (corresponding author) \\ The Education University of Hong Kong \\ 10 Lo Ping Road \\ Tai Po, New Territories \\ Hong Kong SAR \\ badamson@ied.edu.hk Tel: +852 29486157
}

\section{Katherine Forestier}

The Education University of Hong Kong

10 Lo Ping Road

Tai Po, New Territories

Hong Kong SAR

katherine.forestier@gmail.com Tel: +852 29486157

\section{Christine Han}

UCL Institute of Education, University College London

20 Bedford Way

London WC1H 0AL

UK

c.han@ucl.ac.uk Tel: +44 2076126964

\section{Paul Morris}

UCL Institute of Education, University College London

20 Bedford Way

London WC1H 0AL

UK

paul.morris@ucl.ac.uk Tel: +44 2076792000

\section{Acknowledgements}

We would like to acknowledge the funding received from the UK Economic and Social Research Council/Hong Kong Research Grants Council Joint Research Scheme under Grant ES/K010433/1. Views expressed are those of the authors.

\section{Disclosure statement}

Bob Adamson, Katherine Forestier, Christine Han and Paul Morris acknowledge they have received no financial interests or benefits arising from the direct applications of their research.

Key words: Policy borrowing; education reform; international tests

Bob Adamson is Chair Professor of Curriculum Reform and UNESCO Chairholder in Technical and Vocational Education and Lifelong Learning at The Education University of Hong Kong.

Katherine Forestier is an education consultant and journalist in Hong Kong.

Christine Han is Senior Lecturer in Education at UCL Institute of Education, University College London.

Paul Morris is Professor of Comparative Education at UCL Institute of Education, University College London. 


\title{
PISA, policy making and political pantomime: education policy referencing between England and Hong Kong
}

\begin{abstract}
Since the mid-1980s, a number of East Asian societies have consistently performed well in international tests, and their education systems have emerged as models of "best practice", including Hong Kong, which has been extensively referenced by politicians and their advisers in England. In parallel, local dissatisfaction with the education system in Hong Kong has prompted major education reforms. This mismatch between the two policy communities in their perceptions of Hong Kong education is explored using documentary analysis and semistructured interviews with policymakers and other key stakeholders. We analyse the ways in which features of Hong Kong's education system are reconstructed in policymaking in England and argue that the referencing is political theatre, reminiscent of a pantomime, with stereotyped villains and heroes, narratives of good conquering evil, and comical set-pieces. However, there is a darker side to this form of comparative education that involves the manipulation of an unwitting audience.
\end{abstract}




\section{PISA, policymaking and political pantomime: education policy referencing between England and Hong Kong}

\section{Introduction}

Since the creation of systems of mass public education, national governments have looked beyond their borders for inspiration on how to develop and improve their education systems. The long-standing practice was for the developing world to look to the education systems of the powerful, affluent and industrialized West but, since the introduction of international tests of pupil achievement in the mid-1980s, the source of models of good practice has shifted to other sites (Barrett and Crossley 2015). Studies such as those carried out by the Programme for International Student Assessment (PISA) are especially attractive to policymakers as they can be portrayed as providing objective and global evidence of the comparative effectiveness of school systems. The powerful influence of these tests has resulted in both the processes of education policymaking and the nature of policy in nation states increasingly operating within a transnational or global context (Rizvi and Lingard 2010; Carney 2012). This has been facilitated by the emergence of a global network of consultancies and edu-businesses - such as McKinsey, the Grattan Institute, and Pearson - which have used the test results to identify good practice and promote educational reform.

High performing systems are subsequently cited as models for emulation (Steiner-Khamsi 2004; Crossley 2014; Forestier 2015), and used to provide "evidence" of good practice to legitimate policy reforms. The consistently strong performance of pupils from a number of East Asian societies and some Scandinavian countries (especially Finland) (Grek 2009; Alexander 2010) has ignited policymakers' interest in the education policies and practices of these "high performing" education systems. The propensity of policymakers to react to the publication of the rankings by seeking a formula for success spurred a growth in both fact-finding missions 
to Hong Kong, Shanghai, Singapore and other destinations (Sellar and Lingard 2013) and panegyric reports on their educational systems. Since the end of the Second World War, the East Asian Tigers have emerged as some of the world's most dynamic and fastest growing economies, which in recent years has been used to support the alleged direct causal connection between good performance on PISA (and similar tests) and the subsequent rate of economic growth (Organisation for Economic Co-operation and Development 2010; Hanushek et al. 2013).

The process of seeking solutions from other systems involves a complex range of functions and forms of cross-system policy engagements (Thompson and Cook 2015). It is variously described as 'borrowing' (e.g., Phillips and Ochs 2004), 'appropriating' (Phillips 2000), 'recontextualising' (Bernstein 1996; Dowling 1998), 'hybridising' (Schriewer 2012), 'learning' (Raffe 2005), 'reorienting' (Adamson, Nixon and Su 2012), 'referencing' (Steiner-Khamsi 2002), 'transfer' (Perry and Tor 2009), 'importation' (Lauder 2000), and other related terms. We use the term 'policy referencing' to recognise that the process may be rhetorical, symbolic or theatrical as well as (or instead of) involving the actual transfer and implementation of policies and/or practices from one system to another. When external policies are referenced, they may be appropriated or adapted, or not implemented faithfully; they may primarily serve as a symbolic linking to external or global trends designed to legitimize reform in the politics of policymaking (Phillips 2004; Steiner-Khamsi 2004; Stone 2004; Waldow 2012; Auld and Morris 2016). From the perspective of policymakers, referencing other education systems is an attractive strategy as this can be portrayed as providing an evidence-based, and externally-legitimized rationale for reform and, hence, as objective, non-ideological and scientific (Ozga and Jones 2006). The notion that referencing is an essentially symbolic, expedient and ideologically-driven activity matches Rappleye's political production model (Rappleye 2012). The process involves politicians engaging in a form of "political theatre where specific actors, driven by ideological 
and political agendas consciously script opportunities to "get their message out" by articulating it in "references to elsewhere" (Rappleye 2012, 136), with the aim of catalysing and shaping policy change based on their existing ideological stance.

David Bell, who was closely involved in the process of referencing as a former Permanent Secretary for Education in England, explained the deployment of policy referencing in England for both these purposes:

You use your international comparisons to make both political and educational points, and they can inform your policy, but in the end you're still likely to sit with your own ideological instincts. And some people may call that skewing the evidence. I don't. I actually think it's ... lining up the evidence. ... And maybe we just have to accept that politics will always come to the fore, that you use international comparisons as much for political rhetoric as you do, sort of, for detailed policy. (Bell, interview, October 2014)

This study investigates the referencing of Hong Kong in educational policymaking in England since 2010. (The focus is on referencing by England rather than the United Kingdom, as the former's education policies are determined separately from those of other constituent members of the latter.) We argue that, in the case of England, the nature of the political theatre was more akin to a form of pantomime. A pantomime is a form of entertainment similar to Aristophanist comedy that provided light relief after the cathartic experience of tragedies in classical Athens. The pantomime tradition that has developed in England has a strong element of farce, is targeted at children and involves extensive audience participation; cross dressing; and the suspension of disbelief/reality. It typically loosely reworks a folk/fairy tale about heroes triumphing over villains, with comic and romantic elements lightening the mood. We argue that politicians in England consciously reworked the discourse and reality of elements of the 
Hong Kong education system in order to script a narrative that justified their desired reforms. This script was laden with caricatures; it cheered good practice and hissed at evil forces. It was distinctly enamoured of the more traditional aspects of education in Hong Kong, while its superficiality and manipulation of the evidence bordered on farce.

Hong Kong and England provide complex and instructive contexts for investigating the nature and processes of external referencing in policymaking which is of both a substantive and rhetorical nature. The two societies have strong historical linkages, are widely seen as paradigmatically "Western" and "Eastern", are heavily engaged in education reform, have actively undertaken forms of voluntary external policy referencing, and are deeply embedded in global policy networks. We highlight the nature of the referencing of Hong Kong by English policymakers by comparing the "good practices" they identified to the views of the policy community in Hong Kong towards those practices.

\section{Research Methods}

The research team comprised academics in England and Hong Kong. Data were collected between December 2013 and June 2014 in accordance with the ethical protocols of the Hong Kong Institute of Education and the UCL Institute of Education, London. In England, the sources of data were policy briefings, written or oral public statements, and semi-structured, in-depth interviews with 11 members of the policy community involved in developing and implementing education reforms in England (including the former and serving ministers with a responsibility for education, senior civil servants, and academics advising them - ministers and senior civil servants - on the reforms). The interviews allowed us to go beyond the rhetoric of documents so as to explore the experiences, perceptions and attitudes of these policy actors. To ascertain the local perceptions of the Hong Kong system, we analysed curriculum policy documents and interviewed 23 individuals who were active members of the policy community. They included 
policymakers, school principals, academic advisors, overseas experts, leaders of youth groups, leaders of parent organisations, and representatives of employer organisations. Many interviewees had multiple cross-over roles across policy and practice, and some had emic-etic comparative perspectives as international experts working in Hong Kong. The interviewees were selected on the basis of their system-wide experience and knowledge, and influence on the policymaking process. In both research sites, the interviews were conducted in English, and prior informed consent was gained from all participants; some interviewees requested anonymity; others consented to the use of their names.

In analysing the data, we used the "Framework" approach of Ritchie and Spencer (1994) for applied policy research. The five-stage process comprised familiarization, identification of a thematic framework; indexing; charting; mapping; and interpretation. Themes were clustered so that predominant views could be discerned based on the frequency with which they occurred in the various data sources. The findings facilitate an enhanced understanding of how externally referenced education features and systems are perceived, used, and manipulated in policymaking, so as to develop and derive lessons about the nature and role of external policy referencing, both between the two contexts studied, but also more generally.

\section{Villains and heroes}

Under England's Conservative-led Coalition (2010 to 2015) and Conservative government (2015 to present), politicians have increasingly eschewed the advice of academic advisers and their own civil servants, preferring to seek the views of Special Advisers and to commission multinational consultancy firms. Academics in university education faculties came under particularly virulent attack from the government, derided by the then Secretary of Education Michael Gove as key members of 'the Blob', who were described as 'enemies of promise' and 'guilty men and women who have deprived a generation of the knowledge they need' (Gove 
2013). In the same article he made it clear that he would neutralise the influence of this Blob in teacher education and the local authorities that had been responsible for overseeing schools in England. Nick Gibb, the current Minister of School Reform, also portrayed academics as villains, as this question asked in the House of Commons on the release of the 2012 PISA results shows:

Does he [Michael Gove] share my view that university education faculties, which have trained generations of teachers, should take their share of blame? Should not the Institute of Education and Canterbury Christ Church, two of the biggest teacher training institutions, be held to account, not only for today's poor figures but for the country's long tail of underachievement?

Gove responded that Gibb had hit 'several nails squarely on the head' (House of Commons Hansard, 3 December 2013, Vol 571).

The performance of English pupils in PISA in 2012 was portrayed by policymakers as poor and requiring the instigation of transformative reforms. After the PISA results were announced, Gove lamented that education in England was falling behind other systems. It had:

... plummeted in the world rankings from 4th to 16 th for science, 7 th to 25 th for literacy and 8th to 28th for maths [while] from Shanghai to New Orleans, Alberta to Hong Kong, Singapore to Helsinki, nations which have been educational back markers [sic] have become world leaders. (Gove 2012)

He stated that the recently published Schools White Paper was 'deliberately designed to bring together - indeed, to shamelessly plunder from - policies that have worked in other highperforming nations'. Hodgson and Spours $(2016,15)$ describe this response as typical of an "Anglo-Saxon" model, characterised by 
... a focus on international competition; centralised around the role of the Secretary of State for Education; keen to use international comparison for "cherry picking" "best practice" and with an emphasis on radical change rather than learning from the past. They contrast the approach of England with that of the "Celtic fringe" (Scotland, Wales and, to a lesser extent, Northern Ireland) where the responses to PISA were less intense, more collaborative, consensual and context-based, and took historical lessons into account (Hodgson and Spours 2016).

\section{Hong Kong as fairytale}

Hong Kong's education system allured and seduced English policymakers (Sellar and Lingard 2013; You and Morris 2015; Forestier and Crossley 2015). It was first signalled as a possible source of reference in the preliminary report of the International school effectiveness research project (1995), led by David Reynolds, and in a subsequent publication, Worlds apart? (Reynolds and Farrell 1996), derived from that study, which specifically promoted the importance of a didactic whole-class teaching pedagogy. More recently, Hong Kong's education system was referenced in consultancy reports by Barber, Donnelly and Rizvi (2012) and the Grattan Institute, the latter of which argued that 'Hong Kong provides a leading example of successful education strategy and implementation' (Jensen et al. 2012, 23). A Government report (Ruddock and Sainsbury 2008), which compared England's mathematics, science, and literacy curricula with that of high performers in PISA, highlighted Hong Kong, along with Singapore and South Korea.

The English policy community identified a number of specific facets of education in Hong Kong as explaining the strong performance in international tests: high curriculum standards, quality of teaching, and school autonomy. 


\section{High Curriculum Standards}

Hong Kong was referenced in policy documents produced in the run-up to the revised National Curriculum for English schools, such as The Framework for the National Curriculum: A report by the External Panel for the National Curriculum review (DfE 2011), and hard work and memorisation were noted as factors in high performance:

The emphasis on effort is particularly marked in the Confucian-heritage countries such as China, Hong Kong SAR, Singapore, South Korea, and Taiwan. The assumption here is that deep engagement with subject matter, including through memorisation where appropriate, leads to deeper understanding. (DfE 2011, 45)

Official speeches and statements affirmed the Government's position that it wanted a curriculum, qualifications and standards on a par with high-performing systems. For example, Michael Gove (2012) stated that 'Our curriculum reforms were inspired by the high expectations for all children in Singapore and Hong Kong'. The mathematics curriculum received particular attention - maybe because the other two core subjects in Hong Kong schools, Chinese as a first language and English as a second or foreign language, have less relevance for England - and was admired for its challenging content, as confirmed by Sir David Bell, former Permanent Secretary for Education in England:

What actually emerged in the maths curriculum ... [was] content that was assumed to be capable of being tackled by primary-aged children in Hong Kong, that had never been assumed to be capable of being tackled by primary-aged children in England. (Bell, interview, October 2013)

Tim Oates, who chaired the Expert Panel of the Review of the National Curriculum in England, concurred, although he focused on textbooks: 
Hong Kong has very high quality maths textbooks. You know, I have ... closely analysed the different writing frameworks for textbooks around the world, looked at the different elements and how they are combined, how they are driven by different pedagogic models, and the Hong Kong textbooks score extremely highly. (Oates, interview, July 2014)

The Schools Minister, Nick Gibb MP, visited Hong Kong and was enthused by what he observed in mathematics lessons:

I'm very clear ... we need to teach maths in the traditional way that they do in Hong Kong, which is teaching the algorithms, and practice, practice, practice. (Gibb, interview, September 2013)

\section{Quality of Teaching}

The policy community from England also identified the quality of teachers and teaching as a contributor to Hong Kong's success. Barber and Mourshed (2007), in a report published by McKinsey and Company, highlighted the fact that teachers in Hong Kong were drawn from the top 30 percent graduating each year from the school system. The McKinsey report was extensively referenced by policymakers in England (Alexander 2012; Auld and Morris 2014). In terms of the quality of teaching, the McKinsey report influenced the decision to raise the academic entry requirements for trainee teachers in England, and was used to justify the move to school-based teacher education programmes. (Alexander 2012).

Teacher-pupil interaction, and the role of classroom layout in this, won admiring praise from Gibb (interview, September 2013):

[Teachers] taught as a whole class... [The pupils'] desk configuration was very traditional, mostly facing the front; they weren't in groups .... Concentration levels 
were higher ... behaviour was immaculate ... It had not been overly affected by progressive education.

Such perceptions of the importance of 'traditional' whole class teaching to student achievement have given rise to innovations in England, such as a scheme that recruited teachers from Shanghai to replicate these pedagogical approaches in English schools. Gibb was quoted as saying that importing Chinese pedagogical methods for teaching mathematics had been 'hugely successful' (Weale, 2015) and the most valuable innovation the Government had undertaken.

\section{School Autonomy}

Policymakers in England and their advisers referenced Hong Kong in their argument for enhanced school autonomy, on the grounds that it had enhanced competitiveness and subsequent high performance; for example, the Secretary/Minister for Education stated:

In its most recent international survey of education, the OECD found that in countries where schools have greater autonomy over what is taught and how students are assessed, students tend to perform better. Two of the most successful countries in PISA international education league tables - Hong Kong and Singapore - are amongst those with the highest levels of school competition. (Gove 2012)

Gove (2013) added that the East Asian examples demonstrated 'a strong correlation in these league tables between freedom for heads - in systems - and improved results'. Such references provided the basis for the Government's decision to 'dramatically increase the number of academies and free schools - and give heads more control over teacher training, continuous professional development and the improvement of underperforming schools'. You and Morris (2015) identify reforms in three areas related to autonomy that were legitimized by this rhetoric: greater autonomy in the governance and management of schools; the delegation to schools of 
decisions concerning the curriculum and the school calendar; and, decisions related to the recruitment of teachers and determining their salaries.

\section{The fairytale demythologised}

Hong Kong, a British colony from 1841, was restored to Chinese sovereignty in 1997 whereupon a review of the aims of education was conducted by the Education Commission, a group of advisers to the government that represented various local interest groups. A public consultation was carried out, and the commission also looked at education systems in Shanghai, Taipei, Singapore, Japan, South Korea, Chicago, and the USA (Education Commission 2000). This process led to the introduction of the Learning to Learn curriculum in 2001, and of the New Academic Structure (NAS) in 2009. Learning to Learn infused subject knowledge with four key tasks - Reading to Learn, IT for Interactive learning, Moral and Civic Education; and Project Learning — while generic soft skills, in particular communication, critical thinking and creativity, were emphasized (Curriculum Development Council 2001). The NAS changed the structure to six years' secondary and four years' tertiary education and included a New Senior Secondary Curriculum (NSSC) (Education and Manpower Bureau 2005), and assessment. This replaced the 3:2:2 structure of secondary schooling with a 3:3 structure and ruptured the former alignment with the educational structure/system in the UK (excluding Scotland). The extensive recruitment of academic consultants and curriculum experts from overseas (especially Australia and the UK) to support the implementation of reforms relating to curriculum content, assessment and school improvement suggests that Hong Kong's approach to policy referencing was driven by a genuine interest in changing practice rather than a more symbolic and legitimatory function. 
These reforms were instigated despite the evidence of continuing strong performance by Hong Kong pupils in international tests dating from the 1980s, when Hong Kong joined the Second International Association for the Evaluation of Educational Achievement (IEA) Mathematics Study (Garden 1987). For example, in the Trends in International Mathematics and Science Study of 1995, seventh and eighth grade pupils in Hong Kong were ranked fourth in mathematics out of 41 participating countries or systems (IEA 2015), and when Hong Kong first participated in PISA in the 2002 exercise, its 15-year-olds came first in mathematics, third in science and sixth in reading (Education Bureau 2016). Clearly, these achievements were not perceived as an endorsement for maintaining the status quo in the education system. Zhao (2015) suggests that a feature of the Hong Kong education system is the commitment to futureoriented reforms characterised by a focus on skills to cope with the changing economic climate. A study by the Organisation for Economic Co-operation and Development (OECD) (Breakspear 2012) of 37 education systems reported that Hong Kong was only 'moderately' influenced by the PISA results of 2009, in contrast to the reaction in England, where education policies were deemed 'very' influenced by PISA. While the feedback from PISA was valuable and affirming, Hong Kong policymakers — as noted above - focused on a range of sources of evidence when reviewing their educational policies.

Unlike English policymakers, the Hong Kong interviewees did not focus on factors relating to schools, teachers and teaching to explain their students' good performance. Instead, they pointed to values and other factors outside the classroom, such as diligence and extra tuition, as contributing to examination success and, by extension, good PISA scores. As Elliott (2014) notes, there is a focus in Hong Kong on out-of-school factors that can also explain PISA success in other high performing East Asian societies. A policymaker who had moved to Hong Kong from overseas (Policymaker 2, interview, December 2013) suggested that 'East Asians have a 
lot to teach us around perseverance and value of hard work'. This view was supported by another policymaker:

In a social context like Hong Kong, the human capital is the real capital that we can rely on. So parents invest extra resources, extra time and energy to support their children to get good grades in basic education. (Policymaker 4, interview, May 2014)

The specific aspects of the Hong Kong education identified above that were eulogised by the English politicians were thus perceived very differently by the local policy community.

\section{Demanding curriculum}

The association by English policymakers of deep engagement and memorization with the high performance in PISA, did not impress stakeholders in Hong Kong. The view of Sun Kwok, the Dean of Science at the University of Hong Kong, was typical. He wrote:

While Hong Kong students can calculate mathematical problems very quickly and accurately, they have no idea what maths is for.... [T] heir idea of maths is to mechanically and repeatedly grind through formulas. When asked what mathematics can do to solve problems around us, few can give any answers. ... It is clear that the quality of education cannot be measured by standard tests. Instead, we must measure our students by their ability to innovate and compete in the modern world. (Kwok 2015) This critique echoes long-standing concerns regarding the pedagogy of the mathematics curriculum, which called for a shift from the predominant Platonist model (based on teacher instruction) to a social constructivist approach (Chen and Leung 2013). The intention of the Learning to Learn reform at the turn of the millennium was therefore to replace rote-learning with more problem-based learning, logical thinking, creativity and collaborative work (Curriculum Development Council 2001). Similar moves were advocated across all subjects in 
the curriculum. The rationale the Education Commission offered when pushing for these reforms was that:

School life is usually monotonous, students are not given comprehensive learning experiences and have little room to think, explore and create. ... To make up for these weaknesses, we need to uproot outdated ideology and develop a new education system that is student-focused. (Education Commission 2000, 29)

According to Policymaker 2 (interview, December 2013), the new curriculum is 'really, really strong' and 'getting the basics right', with standards being 'professionally and technically set' and valuable 'cognitive interchange' taking place between mathematics and learning Chinese and English. One reason for this improvement, according to Academic Advisor 1 (interview, December 2013), was the fact that 'We [Hongkongers] really have very good subject experts'. Liberal Studies, a new compulsory interdisciplinary subject introduced in the NSSC which sought to develop pupils' ability to think critically and independently, was also considered by many interviewees to be a strength. Principal 5 (interview, April 2014) felt that Hong Kong was leading the way in having a 'questioning curriculum'. A Deputy Principal (interview, December 2013) agreed, commenting that:

...the introduction of Liberal Studies liberates students' minds and pushes them, stretches them further, to attempt to investigate their world, learn to conduct a study, conduct a learning process on their own, synthesize a lot of data and information and most importantly they ... have choice in their learning.

From the business community, a representative observed that 'Liberal Studies [is] a good step towards ensuring that we have people who are not only employable, but interesting to be employed' (Employer 1, interview, May 2014). 
Although the reforms met with general approbation, there was a lingering dissatisfaction that they had failed to permeate classroom practice to the intended extent. The reasons for this were identified as logistical problems, ideological and cultural resistance, reform overload, and lack of teacher preparation (e.g., Curriculum Development Council, Hong Kong Examinations and Assessment Authority, and Education Bureau 2015). Most of the representatives of parent groups interviewed for our study were disappointed by their children's experiences in school. Specifically they complained that too much lesson time was devoted to the acquisition of knowledge that was often trivial in nature or application. Parent 1 (interview, May 2014) commented: '[My daughter] works so hard... but on stuff that really doesn't matter'. Employer 2 (interview, April 2014) was critical of the narrowness of the curriculum:

With the exception of a handful of schools, there's not enough focus on inquiry-based learning, creativity around thought processes. There's very little focus on international exposure.

\section{Teacher quality}

Stakeholders in Hong Kong tended to recognize teachers' diligence but were highly critical of their pedagogy and the learning outcomes. For example, Principal 2 (interview, December 2013) considered Hong Kong teachers 'very, very hardworking', but most of the Hong Kong stakeholders we interviewed were less positive about the quality of teaching. As Parent representative 1 (interview, May 2014) put it:

You may have very committed teachers... very kind ... great pastoral care, but the system is skewed towards training good behaviour in students rather than inspiring them intellectually. ... I don't expect my daughter to learn anything ... because the teachers' quality isn't that fantastic. 
These views might seem to validate Gibb's characterization of classroom interaction as teachercentred, but the Hong Kong policy community did not share his enthusiasm for relying predominantly on whole-class teaching, nor for his view that PISA results could be taken as a proxy for the quality of education. The consensus in Hong Kong was that the long-standing teacher-centred, rote-learning approaches were counterproductive in achieving Hong Kong's aims of education. One local academic adviser commented sarcastically that Hong Kong was 'top of the world' for instructional time (Academic Advisor 1, interview, December 2013). A parent representative expressed frustration, noting:

There are a lot of drills. That helps explain why they do better in exams. ... Teachers don't tolerate questions - they see questions as a challenge to [their] authority.... It is all about covering syllabuses. It's all quantitative, nothing qualitative. This is what's so upsetting to parents. (Parent 2, interview, December 2013)

The focus on testing as a prevalent feature of Hong Kong schools was seen as detrimental to pupils:

This is her fifth set of exams for this academic year, and these are not easy exams. This is in addition to small Maths tests and dictation every week. ... They're constantly tested. (Parent 1, interview, May 2014)

Principal 1 (interview, December 2013) commented on how, from Secondary 5 onwards, extra lessons and make-up classes added 40 extra school days a year in his school. In addition, as Policymaker 5 (interview, February 2014) argued, the ubiquitous provision of private tuition merely reinforced test-centred approaches:

Parents will send their children to tutorial schools after formal school. Tutorial school is usually still drill, practice and then taking quizzes and extra quizzes and tests.

Such teaching approaches not only frustrated students and parents, but were also perceived to have a negative effect on the competencies in the workplace. An employer reported that a result 
of the focus on testing and teacher-centred pedagogy was a lack of initiative in young people entering the workforce:

$[\mathrm{O}]$ ne of the things that we constantly hear [from employers] is recent graduates are very good at executing what they're told to do. What they're not so good at is figuring out what needs to be done. (Employer 1, May 2014)

In general, therefore, members of the Hong Kong policy community did not view teacher quality as a positive or salient feature of education in Hong Kong. Indeed, they did not see teaching as a career that attracted the strongest graduates. Policymaker 4 (interview, May 2014) bluntly commented:

If you look at the quality of qualifications of people coming into teaching, it's lower than in other kinds of professions.

Hence, the role of quality of teaching in student achievement was understood quite differently by English policymakers and Hong Kong stakeholders, with the latter tending to attribute student success to out of school factors, such as values like diligence, as well as the use of private tuition.

\section{School autonomy}

School autonomy and accountability in Hong Kong had been subject to reform from the mid1990s as school-based management was phased in, transferring management from sponsoring bodies (primarily religious groups) to Incorporated Management Committees, and creating new processes of school review and self-evaluation (You and Morris 2015). The promotion of school autonomy involved two distinct strands. The first began around 1991 and involved the creation of Direct Subsidy Scheme (DSS) schools which were allowed greater latitude in a number of areas of decision making, including the deployment of resources, curriculum design and pupil admission. These schools now comprise $9 \%$ of secondary schools in the mainstream 
system and consist of a mixture of ex-communist schools (which obtained public funding by joining the scheme) and elite and new schools that were, by virtue of joining the scheme, able to select pupils and charge fees. The second strand involved a move to establish an Incorporated Management Committee for all schools, which was implemented from 2009 (Cheung and Kan 2009). Whilst this latter policy was promoted by the Government through a discourse which stressed the value of decentralization and reflected the dominant neo-liberal discourses of globalization, competition, and the post-industrial knowledge economy (Dale 1997; Lee 2014; Marsh, et al. 2014), it was seen locally as an attempt to reduce the power of the main bodies (especially Catholic and Protestant church groups) that ran schools (Cheung and Kan 2009). The school evaluation system, introduced in 2003 and revised in 2008, was developed with input from senior inspectors and academics from Scotland and features a mix of self-evaluation and external review focusing on formative feedback. Its purpose was to provide guidance on how to improve learning outcomes as well as to strengthen the accountability of schools (Morris and Adamson 2010).

Four of the principals we interviewed reflected positively on Hong Kong's system for holding schools accountable. Principal 1 (interview, December 2013) explained that school inspections served as a 'driver for improvement' without deploying any mechanism designed to name and shame poor schools. He felt that schools generally received fair assessments, and he liked the strategy used by the external assessors to celebrate strengths first, before considering ways to improve. This supportive role was further enhanced by the inclusion of external school principals on review panels, facilitating the sharing of good practices.

However, there was considerable variation in the degree of autonomy enjoyed by schools. While the vast majority of publicly-funded schools might enjoy some autonomy (in financial matters, for example), this freedom is far more restricted than that enjoyed by the DSS schools. 
Although the policy intention promotes autonomy in pedagogy in curriculum, this is limited in practice. As Policymaker 5 (interview, February 2014) noted:

Autonomy's an odd word to use about Hong Kong's schools .... It doesn't develop autonomy amongst students. It doesn't expect autonomy from teachers....Teachers ... are told, quite strictly, as I understand it, by senior staff within the school what they're expected to do in the classroom, whether they agree with it or not.... A lot of them have to give way and regress to more traditional, spouting methods.

In senior secondary schools, autonomy appeared to be tempered by intense competitive pressures facing Hong Kong schools, in both attracting pupils and securing good public examination results for future pupil recruitment. According to Principal 2 (interview, December 2013):

Teachers are under great pressure to have their students pass exams, so I don't see much autonomy... If you are talking about lesson time, if you're talking about teacher workload, I don't think they have many choices. But in junior forms, yes, relatively, we do have greater autonomy.

Another principal (Principal 3, interview, December 2013) attributed this general lack of teacher autonomy to an 'Oriental culture, of subordinates looking up to superiors'.

It seems, therefore, that Hong Kong schools were allowed scope for self-improvement under the leadership of the principals, but the fiercely competitive environment induced many to focus more on examination results, particularly for senior forms, than on pedagogical innovation. At the level of school inspection, however, the system of school accountability including a process for self-evaluation — was a positive one that encouraged improvement. This generally positive tenor of the attitude to the inspections was not however, an aspect of education that was borrowed by the English education reforms, which, instead, persisted in 
deploying a regulatory system that has been described as 'exploiting and, in turn, contributing to a complex nexus of "victimisation" of the teaching profession' (Case et al.. 2000, 619).

It also needs to be recognized, as You and Morris (2015) note, that autonomy consisted of conferring greater power on principals for differing reasons in England and Hong Kong. In the latter, autonomy was associated with (a) emasculating certain school managing bodies, while also allowing school principals greater managerial power and space for curricular innovation; and (b) a means to allow a small proportion of schools to select their intakes and charge fees. In the move towards enhancing autonomy for all schools in England, policy discourse dressed up the Hong Kong reforms as having led to improved learning and teaching, a conclusion that was disputed by interviewees there, who, as noted above, felt that school principals used autonomy to strive for competitive/improved examination results. In England, the power of principals to innovate in schools was severely constrained by a more punitive system of accountability, suggesting that the purposes of the reforms were more concerned with the establishment of free schools and academies than with granting principals and teachers greater pedagogical freedom.

\section{Policymaking as Pantomime}

The considerable discrepancy between what policymakers from England and the consultants, such as McKinsey, identified as good practices in Hong Kong schools, and what local stakeholders considered to be strength involves a suspension of disbelief on the English side. By searching for a magical solution or silver bullet, they created an illusion of Hong Kong's education system that adhered to the conventions of a political script. Allusions to Hong Kong (and elsewhere in Asia) provided a mixture of real and fictional evidence for the promotion of ideologically-charged reforms, with PISA results acting as a convenient trigger. A myth of academic excellence was generated based on selective data and sleight-of-hand to justify the 
reforms in England. Heroes were mythologised and embraced; ideological opponents were vilified. This farcical exercise degenerated further when Hong Kong departed from the script. Notwithstanding high PISA scores and driven by changes in social and economic needs, the Hong Kong authorities embarked upon reforms that were greeted with hoots of dismay by policymakers from England. Gibb's visit to Hong Kong in 2010 coincided with the introduction of the NSSC. His reaction suggested that he feared that the Hong Kong policy community had been duped by the evil Blob:

I just thought, oh my goodness, don't do this. ....It's all the stuff we were fighting against in [England], that you were absorbing hook, line, and sinker: the creative curriculum, skills-based curriculum... (Gibb, interview, September 2013)

In rejecting the Hong Kong reforms, the English policymakers adopted two arguments. The first, articulated by Gibb, represents an ideological difference of opinion concerning the nature and orientation of the school curriculum. The second was based on their quest for evidence: Tim Oates (interview, July 2014) explained that the subsequent Review of the National Curriculum by the Expert Panel in 2011 was interested in factors in place when Hong Kong pupils who were tested in PISA in 2009 had embarked on their primary schooling, rather than the NSSC reforms that were regarded as unproven in their impact on PISA results. Thus the English politicians preferred to reference pre-reform practices in Hong Kong, even though these were perceived as unfit for purpose in meeting the goals of education by Hong Kong stakeholders.

In order to derive lessons from the better-performing systems, the English policymakers draw upon a mixture of the PISA data and broad-brush comparative reviews by commercial consultancies and policy think tanks. The data and the accompanying analysis are framed to facilitate the identification of specific key factors (such as a demanding curriculum, good 
quality teachers and a high degree of autonomy for school principals) that are claimed to bring about strong PISA scores, which in turn are associated with strong economic productivity. This approach requires a dash of fairy dust: in the absence of an ability to establish a causal connection between the input factors identified and the desired outputs (Auld and Morris 2016; Forestier 2015; Gillis, Polesel, and Wu 2016) it relies on speculation, impressions, correlations and assertions to fill the vacuum. In Hong Kong, in contrast, overseas academics and specialists in specific areas are brought in to synthesise their expertise/support implementation with that of local stakeholders. Together, they are able to draw upon more contextualised understandings of, and interactions with, the Hong Kong education system. The resultant reforms tend to be more holistic, addressing issues inside and beyond the classroom and school, rather than focusing on narrow strategies.

Another approach adopted by policymakers from England is to undertake short visits to those systems that top the PISA rankings, to gain a personal insight into the factors contributing to the good outcomes. Such visits are necessarily subjective and selective, and therefore subsequent conclusions are prone to be influenced by pre-existing ideological lenses. As we saw above, visitors tended to use their own cultural lens to identify whatever confirmed their a priori beliefs - a trend noted elsewhere by Humphrey (2002) and Steiner-Khamsi and Stolpe (2006). Nick Gibb reflected candidly:

I wanted to see good things, because I wanted to take the good things and bring them here. ...I knew what I was looking for, I wasn't there as an innocent seeing schools and saying, 'right, Hong Kong's great, let's copy everything'. I was looking for particular things.... And I saw what I expected to see ... Traditionally taught, practice is important... and the kids were achieving. (Gibb, interview, September 2013) 
He admitted that it may have been a weakness of the exercise not to consider more deeply the limitations of the Hong Kong system as identified locally. Indeed, many attributes admired by the English policymakers were actually viewed as problems needing rectification in Hong Kong. None of the three areas of strengths highlighted by the former in this study-a demanding curriculum, the quality of teachers and school autonomy—was perceived by the Hong Kong respondents as a specific reason why pupils performed well in PISA or as an indicator of an outstanding education system. However, they did suit the agenda of English policymakers in different ways. One was to transpose 'good practices' in pedagogy that fitted the policymakers' preference for 'traditional' teaching methods (such as drilling and more demanding content in mathematics); another was to refer to practices (such as school autonomy) in Hong Kong to legitimize a policy in England that actually had little substantively in common with the object being referenced. This manipulation of data was deemed justifiable by David Bell, the former Permanent Secretary, as a coup de théâtre performed by politicians: You have to accept, do you not, that the politician, the elected politician, has got the right to say 'my political beliefs', or 'my ideology drives me more likely in this direction than that direction', not quite irrespective of what the evidence says, but the evidence will be orientated, in a sense, to get behind my ideology.

Our analysis has focused on Hong Kong and how it is referenced by English policymakers. Other literature (e.g., Han 2016; Dimmock and Tan 2013; You and Morris 2015) would suggest that a similar pattern is evident in the references made by English policymakers to other nations whose pupils perform well on cross-national tests. The study demonstrates — once again how the use of international comparisons in education by policymakers and their advisers is fraught with fantasy, and is redefining how the applied strand of comparative education works. The 'pick and mix' solution runs the risk of failing to heed the famous caution by Sir Michael Sadler (1900, reprinted 1964) against ignoring the cultural context in which practices are 
embedded and, consequently, the recognition that factors outside schools are more important than those within. Consultants who produced comparative reports for government have been criticized for providing 'desk reviews... [that] most conspicuously illustrate the dangers of illconceived international comparison in the context of educational policy' (Alexander 2012, 7). As Novoa and Yariv-Mashal (2003) observe, comparative education as led by global policy bodies such as the OECD has moved away from seeking to understand and compare the other, to measuring the other. Its function nowadays can be described as 'comparison advocacy harnessed to the task of winning imaginary contests and competitions, such as the global "war for talent", the "education race" and "skills race" (Morris 2016, 5). Comparative educationalists have been corralled into participating in a policymakers' pantomime drama, as heroes, villains or small bit players writing pantomime scripts.

\section{Acknowledgements}

We would like to acknowledge the funding received from the UK Economic and Social Research Council/Hong Kong Research Grants Council Joint Research Scheme under Grant ES/K010433/1. Views expressed are those of the authors. 


\section{References}

Adamson, B., J. Nixon, and F. Su. 2012. "Comparative Education and the Reorientation of Higher Education." In The Reorientation of Higher Education: Challenging the EastWest Dichotomy, edited by B. Adamson, J. Nixon, and F. Su, 12-34. Hong Kong and Dordrecht: Comparative Education Research Centre, University of Hong Kong and Springer.

Alexander, R. J. 2010. “'World Class Schools” - Noble Aspiration or Globalised Hokum? BAICE Presidential Address at the $10^{\text {th }}$ UKFIET Conference on Education and Development 2009." Compare, A Journal of Comparative and International Education 40 (6): 801-817.

Alexander, R. J. 2012. "Moral Panic, Miracle Cures and Educational Policy: What Can We Really Learn from International Comparison?" Scottish Educational Review, 44 (1): 421.

Auld, E., and P. Morris. 2014. "Comparative Education, the 'New Paradigm' and Policy Borrowing: Constructing Knowledge for Education Reform." Comparative Education 50 (2): $129-155$.

Auld E., and P. Morris. 2016. "PISA, Policy and Persuasion: Translating Complex Conditions into Education 'Best Practice'”. Comparative Education 52 (2): 202-229.

Ball, S. J., and C. Junemann. 2012. Networks, New Governance and Education. Bristol: Policy Press.

Barber, M., and M. Mourshed. 2007. How the World's Best-Performing School Systems Come Out on Top. London: McKinsey.

Barber, M., K. Donnelly, and S. Rizvi. 2012. Oceans of Innovation: the Atlantic, the Pacific, Global Leadership and the Future of Education. London: Institute for Public Policy Research. 
Barrett, A. and M. Crossley (2015). "The Power and Politics of International Comparisons." Compare: A Journal of Comparative and International Education 45 (3): 467-470.

Bernstein, B. 1996. Pedagogy, Symbolic Control and Identity: Theory, Research, Critique, London: Taylor and Francis.

Bray, M. 2014. "Actors and Purposes in Comparative Education.” In Comparative Education Research: Approaches and Methods, edited by M. Bray, B. Adamson, and M. Mason, 19-46. Hong Kong and Dordrecht: Comparative Education Research Centre, University of Hong Kong and Springer.

Breakspear, S. 2012. The Policy Impact of PISA: An Exploration of the Normative Effects of International Benchmarking in School System Performance. OECD Education Working Papers, No. 71, OECD Publishing.

Burney, E. 1935. Report on Education in Hong Kong. London: Crown Agents.

Carney, S. 2012. “Imaging Globalization: Educational Policyscapes.” In Policy Borrowing and Lending in Education, edited by G. Steiner-Khamsi and F. Waldow, 339-353. New York: Routledge.

Case, P., S. Case, and S. Catling. 2000. "Please Show You're Working: A Critical Assessment of the Impact of OFSTED Inspection on Primary Teachers." British Journal of Sociology of Education 21 (4): 605-621.

Curriculum Development Council. 2001. Learning to Learn. The Way Forward in Curriculum Development. Hong Kong: Government Printer.

Curriculum Development Council, HKEAA (Hong Kong Examinations and Assessment Authority) and EdB (Education Bureau of the HKSAR). 2015. Continual Renewal from Strength to Strength - Report on the New Academic Structure Medium-Term Review and Beyond. Hong Kong: Government Printing Department. 
Chen, Q., and F. K. S. Leung. 2013. “A Comparative Study of Teachers' Mathematics Beliefs in the Context of Curriculum Reform in Hong Kong and Chongqing." The Mathematics Educator 15 (1): 46-65.

Cheung, S. M. C., and F.L.F. Kan. 2009. “Teachers’ Perceptions of Incorporated Management Committees as a Form of School-Based Management in Hong Kong." Asia Pacific Education Review 10 (2): 139-148.

Crossley, M. 2014. "Global League Tables, Big Data and the International Transfer of Educational Research Modalities. Comparative Education 50 (1):15-26.

Dale, R. 1997. "The State and the Governance of Education: An Analysis of the Restructuring of the State-Education Relationship." In Education, Culture, Economy, Society, edited by A. H. Halsey, H. Lauder, P. Brown, and A. S. Wells, 273-282. Oxford: Oxford University Press.

Department for Education (England and Wales). (2011) The Framework for the National Curriculum: A Report by the Expert Panel for the National Curriculum Review. London: Department for Education.

Dimmock, C., and C. Y. Tan. 2015.'Explaining the Success of the World's Leading Education Systems: the Case of Singapore.” British Journal of Educational Studies 64 (2) 161-184. Dowling, P. 1998. The Sociology of Mathematics Education: Mathematical Myth/Pedagogical Texts. London: RoutledgeFalmer.

Education Bureau of the HKSAR. 2016. Programme for International Student Assessment (PISA). Accessed March 1 2016. http://www.edb.gov.hk/en/edu-system/educationalresearch-projects/pisa/index.html

Education Commission. 1963. Report of Education Commission. Hong Kong: Government Printer. 
Education Commission. 2000. Education Blueprint for the 21st Century: Review of Academic System - Aims of Education. Hong Kong: Government Printer.

Elliott, J.G. 2014. "Lessons from Abroad: Whatever Happened to Pedagogy?" Comparative Education 50 (1): 27-44.

Education and Manpower Bureau of the HKSAR. 2005. The New Academic Structure for Senior Secondary Education and Higher Education - Action Plan for Investing in the Future of Hong Kong. Hong Kong: Government Printer.

Fisher, N.G. 1951. A Report on Government Expenditure on Education in Hong Kong. Hong Kong: Government Printer.

Forestier, K. 2015. "Hong Kong's Success in PISA: An Analysis of Local and International Stakeholder Perspectives.” EdD diss. University of Bristol.

Forestier, K., B. Adamson, C. Han, and P. Morris. Forthcoming. "Referencing and Borrowing from Other Systems: The Hong Kong Education Reforms.” Educational Research.

Forestier, K., and M. Crossley. 2015. "International Education Policy Transfer- Borrowing Both Ways: The Hong Kong and England Experience." Compare, A Journal of Comparative and International Education 45 (5): 664-685.

Garden, R.A. 1987. "The Second IEA Mathematics Study." Comparative Education Review $31(1): 47-68$

Gillis, S., J. Polesel, and M. Wu. 2016. "PISA Data: Raising Concerns with Its Use in Policy Settings." Australian Educational Researcher 43 (1): 131-146.

Gove, M. 2012. Speech to the Education World Forum. Department for Education. Accessed March 12016. http://www.education.gov.uk/inthenews/speeches/a0072274/michael-gove-to-theeducation-world-forum. 
Grek, S. 2009. "Governing by Numbers: The PISA 'Effect' in Europe.” Journal of Education Policy 24 (1): 23-37.

Han, C. 2016. "External Policy Referencing in Education." In Education, Ethics and Experience: Essays in Honour of Richard Pring, edited by M. Hand and R. Davies, 135148. London and New York: Routledge.

Hanushek, E.A., G. Schwerdt, S. Wiederhold, and L. Woessmann. 2013. Returns to Skills Around the World: Evidence from PIAAC. OECD Education Working Paper no.101. Paris: OECD Publishing.

Hodgson, A., and K. Spours. 2016. "Restrictive and Expansive Policy Learning — Challenges and Strategies for Knowledge Exchange in Upper Secondary Education Across the Four Countries of the UK." Journal of Education Policy 31 (5): 511-525.

Humphrey, C. 2002. “Does the Category 'Postsocialist' Still Make Sense?” In Postsocialism: Ideals, Ideologies and Practices in Eurasia, edited by C. M. Hann, 12-15. London: Routledge.

International Association for the Evaluation of Educational Achievement. 2015. TIMSS 1995. Highlights of Results. International Association for the Evaluation of Educational Achievement. Accessed March 12016. http://timssandpirls.bc.edu/timss1995i/HiLightB.html

Jensen, B., A. Hunter, J. Sonnemann, and T. Burns. 2012. Catching Up: Learning from the Best School Systems in East Asia. Melbourne: Grattan Institute.

Kan, V., and B. Adamson. 2010. "Language Policies for Hong Kong Schools since 1997." London Review of Education 8 (2): 167-176.

Kwok, S. 2015. "Hong Kong students need inspiration, not more tests, to excel." South China Morning Post, May 28. Accessed March 12016. 
http://www.scmp.com/comment/insight-opinion/article/1811208/hong-kong-studentsneed-inspiration-not-more-tests-excel

Lauder, H. 2000. "The Dilemmas of Comparative Research and Policy Importation.” British Journal of Sociology of Education 21 (3): 465-475.

Lee, C-K. J. 2014. "Curriculum Reforms in Hong Kong: Historical and Changing SocioPolitical Contexts." In Asia's High Performing Education Systems: The Case of Hong Kong, edited by C. Marsh, and C-K. J. Lee, 17-32. New York: Routledge.

Llewellyn, J. 1982. A Perspective on Education in Hong Kong: Report by a Visiting Panel. Hong Kong: Government Printer.

Marsh, C., P. Morris, and J T-Y. Lo. 2014. "Centralization and Decentralization: An Historical Analysis of School-Based Curriculum Development Initiatives in Hong Kong. In Asia's High Performing Education Systems: The Case of Hong Kong, edited by C. Marsh, and C-K. J. Lee, 33-47. New York: Routledge.

Morris, P. 2000. "Changing the Curriculum." In Changing the Curriculum: The Impact of Reform on Primary Schooling in Hong Kong, edited by B. Adamson, T. Kwan, and K. K. Chan. Hong Kong: Hong Kong University Press.

Morris, P. 2012. “'Pick n' Mix, Select and Project; Policy Borrowing and the Quest for 'World Class' Schooling: An Analysis of the 2010 Schools White Paper.” Journal of Education Policy 27 (1): 89-107.

Morris, P. 2016. Education Policy, Cross-National Tests of Pupil Achievement and the Pursuit of World Class Schooling: A Critical Analysis. Institute of Education, University College of London Press; London.,

Morris, P., and B. Adamson. 2010. Curriculum, Schooling and Society in Hong Kong. Hong Kong: Hong Kong University Press. 
Mourshed, M., C. Chijioke, and M. Barber. 2010. How the World's Most Improved School Systems Keep Getting Better. London: McKinsey.

Novoa, A., and T. Yariv-Mashal. 2003. "Comparative Research: A Mode of Governance or a Historical Journey?" Comparative Education 39 (4): 423-438.

Organisation for Economic Co-operation and Development. 2010. The High Cost of Low Educational Performance: The Long-Run Economic Impact of Improving PISA Outcomes. Paris: OECD Publishing.

Ozga. J., and R. Jones. 2006. "Travelling and Embedded Policy: The Case of Knowledge Transfer." Journal of Education Policy 21 (1): 1-17.

Perry, L.B., and G-h. Tor. 2009. "Understanding Educational Transfer: Theoretical Perspectives and Conceptual Frameworks.” Prospects 38: 509-528.

Phillips, D. 2000. "Learning from Elsewhere in Education: Some Perennial Problems Revisited with Reference to British Interest in Germany." Comparative Education 36 (3): 297-307.

Phillips, D. 2004. “Toward a Theory of Policy Attraction in Education.” In The Global Politics of Educational Borrowing and Lending, edited by G. Steiner-Khamsi, 54-67. New York: Teachers College Press.

Phillips, D., and K. Ochs. 2004. "Researching Policy Borrowing: Some Methodological Challenges in Comparative Education.” British Educational Research Journal 30 (6) 773-784.

Raffe, D. 2005. 'Learning from 'Home International' Comparisons: 14-19 Curriculum and Qualifications Reform in England, Scotland and Wales." Paper presented at the Joint Seminar of the Education and Youth Transitions Project and the Nuffield Review of 1419 Education, March 15 2005. Accessed March 12016. http://www.ces.ed.ac.uk/PDF\%20Files/EYT_SP04_DR.pdf 
Rappleye, J. 2012. Educational Policy Transfer in an Era of Globalization: Theory, History, Comparison. Oxford: Peter Lang.

Reynolds, D., and S. Farrell. 1996. Worlds Apart? A Review of International Surveys of Educational Achievement Involving England. London: Ofsted, HMSO.

Ritchie, J. and L. Spencer. 1994. “Qualitative Data Analysis for Applied Policy Research.” In Applied Qualitative Research, edited by A. Bryman, and R.E. Burgess, 173-194. London: Taylor and Francis.

Rizvi, F., and B. Lingard. 2010. Globalising Educational Policy, London: Routledge.

Ruddock, G. and M. Sainsbury. 2008. Comparison of the Core Primary Curriculum in England to Those of Other High Performing Countries. London: Department for Children, Schools and Families.

Sadler, M. E. 1900. "How Far Can We Learn Anything of Practical Value from the Study of Foreign Systems of Education? Address of 20 October". Reprinted (1964) in Comparative Education Review 7 (3) 307-314.

Schriewer, J. 2012. "Meaning Constellations in the World Society." Comparative Education 48 (4): 411-422.

Sellar, S., and B. Lingard. 2013. "Looking East: Shanghai, PISA 2009 and the Reconstitution of Reference Societies in the Global Education Policy Field." Comparative Education 49 (4): 464-485.

Steiner-Khamsi, G. 2002. "Reterritorializing Educational Import: Explorations into the Politics of Educational Borrowing." In Fabricating Europe: The Formation of an Education Space, edited by A. Novoa and M. Lawn. Dordrecht: Kluwer.

Steiner-Khamsi, G. ed. 2004. The Global Politics of Educational Borrowing and Lending. New York: Teachers College Press. 
Steiner-Khamsi, G. and I. Stolpe. 2006. Educational Import: Local Encounters with Global Forces in Mongolia. New York: Palgrave Macmillan.

Stone, D. 2004. "Transfer Agents and Global Networks in the 'Transnationalization' of Policy.” Journal of European Public Policy 11 (3): 545-566.

Weale, S. 2015. "Trial of Chinese-style maths lessons in English schools to be expanded." The Guardian, August 12. Accessed March 12016.

http://www.theguardian.com/education/2015/aug/12/trial-of-chinese-style-mathslessons-in-english-schools-to-be-expanded

Thompson, G., and I. Cook. 2015. "Becoming-Topologies of Education: Deformations, Networks and the Database Effect." Discourse: Studies in the Cultural Politics of Education 36 (5): 732-748.

Waldow, F. 2009. "What PISA Did and Did Not Do: Germany after the 'PISA-Shock'." European Educational Research Journal 8 (3): 476-483.

Waldow, F. 2012. "Standardisation and Legitimacy: Two Central Concepts in Research on Educational Borrowing and Lending." In Policy Borrowing and Lending in Education, edited by G. Steiner-Khamsi, and F. Waldow, 411-427. New York: Routledge.

You, Y., and P. Morris. 2015. "Imagining School Autonomy in High-Performing Education Systems: East Asia as a Source of Policy Referencing in England.” Compare: A Journal of Comparative and International Education. Advance online publication. doi: 10.1080/03057925.2015.1080115.

Zhao, Y. 2015. Lessons that Matter: What Should We Learn from Asia's School Systems? Melbourne: Mitchell Institute for Health and Education Policy. 